Department of Economics - FEA/USP

\title{
Paying Attention to Inattention: Evidence from Libraries
}

MATHEUS ALBERGARIA

GILBERTO TADEU LIMA

Working PAPER SERIES № 2019-51 


\title{
Paying Attention to Inattention: Evidence from Libraries
}

\author{
Matheus Albergaria (Matheus.fecap@gmail.com) \\ Gilberto Tadeu Lima (giltadeu@usp.br)
}

\begin{abstract}
:
This paper measures inattention in a novel setting, an information commons. Employing a dataset that contains more than 300,000 daily transactions in libraries during a 10-year period, we compare the compliance behavior of library users over weekdays. Since library users get periodic reminders to return books checked out from the library, delays can be arguably interpreted as a form of inattention. If inattention affects rule compliance, then one would expect greater return delays in periods of potentially higher inattention, such as the day before weekends, holidays, and exam weeks, for example. We report the occurrence of a "Friday effect": inattention, as measured by delays in returning checked out books, is consistently higher on Fridays, when compared to the other days of the week. There is no evidence of inattention in dates near holidays, or exam weeks. Taken together, the results reported in this paper represent new empirical evidence related to an important behavioral bias in a real-world setting.
\end{abstract}

Keywords: Behavioral economics; inattention; information commons; reminders.

JEL Codes: D62; D83; H41. 


\title{
Paying attention to inattention Evidence from Libraries
}

\author{
Matheus Albergaria \\ (Corresponding Author) \\ Fund. Escola de Comércio Álvares Penteado (FECAP) \\ Rua José Piragibe, 396 (Ap. 21) \\ Vila Indiana - São Paulo - S.P. \\ 05585-040 - BRAZIL \\ matheus.fecap@gmail.com
}

ORCID Id: https://orcid.org/0000-0003-2788-1269

\author{
Gilberto Tadeu Lima \\ Departamento de Economia \\ Universidade de São Paulo \\ Avenida Luciano Gualberto, 908 \\ Cidade Universitária - São Paulo - S.P. \\ 05508-010 - BRAZIL \\ giltadeu@usp.br \\ ORCID Id: https://orcid.org/0000-0002-0307-8298
}

\begin{abstract}
This paper measures inattention in a novel setting, an information commons. Employing a dataset that contains more than 300,000 daily transactions in libraries during a 10-year period, we compare the compliance behavior of library users over weekdays. Since library users get periodic reminders to return books checked out from the library, delays can be arguably interpreted as a form of inattention. If inattention affects rule compliance, then one would expect greater return delays in periods of potentially higher inattention, such as the day before weekends, holidays, and exam weeks, for example. We report the occurrence of a "Friday effect": inattention, as measured by delays in returning checked out books, is consistently higher on Fridays, when compared to the other days of the week. There is no evidence of inattention in dates near holidays, or exam weeks. Taken together, the results reported in this paper represent new empirical evidence related to an important behavioral bias in a real-world setting.
\end{abstract}

JEL Classification: D62, D83, H41.

Keywords: behavioral economics; inattention; information commons; reminders. 


\section{Paying attention to inattention \\ Evidence from Libraries}

\section{Introduction}

Given the increasing amount of information that most people face today, as well as their cognitive limitations, it is not feasible to simultaneously focus their attention on all events they face (Simon, 1955). As a result, inattention behavior may arise in distinct situations, even when people receive constant reminders to behave in a different manner. Although reminders can work in promoting rule compliance (Apesteguia, Funk, \& Iriberri, 2013), there is evidence suggesting that individuals may not meet a deadline even when it is visibly profitable to do so (Ericson, 2017).

This paper measures inattention in an information commons (libraries). We want to answer the following question: what is the extent of inattention in a real-world setting? Employing a novel dataset comprising more than 300,000 daily transactions in libraries during a 10-year period, we measure inattention as the number of borrowed books per library user not returned when they are due. Libraries arguably constitute an ideal real-world setting for studying inattention, as they clearly establish specific return dates for items checked out by users, and send electronic reminders before (and after) they are due back.

When testing for the possible occurrence of inattention in our data, we distinguish between two competing plausible explanations: one based on procrastination behavior (Ericson, 2017), and the other based on strategic considerations (Guiso, Sapienza, \& Zingales, 2013). If the former prevails over the second type of salient inattention, then one would expect to find a higher proportion of return delays on dates in which procrastination is likely to be more frequent, such as days immediately before weekends, for example. Meanwhile, if strategic considerations, such as keeping a book for a longer period in order to prepare for an exam, were more relevant, then one would expect to detect a higher proportion of return delays in days before exams.

As a preview, our main results suggest that inattention, as measured by delays in returning borrowed books, is mostly a procrastination phenomenon. These results contribute to a growing literature on the empirical measurement of inattention, with a fitting emphasis on the impact of reminders (Apesteguia et al., 2013; Ericson, 2017). By measuring inattention as the average number of book return delays in libraries, we provide a new proxy for an important behavioral bias (Gabaix, 2017). This measure has the advantage of being directly observable and considerably easier to interpret, when compared to previous measures reported in the finance literature, which could be subject to noise and other types of bias derived from the methodology used to build them (Barber \& Odean, 2008; DellaVigna \& Pollet, 2009; Hirshleifer, Lim, \& Teoh, 2009).

\section{Materials and methods}

We study the behavior of library users covering more than 300,000 transactions during a 10year period. We have access to rich confidential daily data related to users of three libraries from a private educational institution in the city of São Paulo, Brazil, for the 2005-2015 
period. The original data contain detailed information on 17,498 individual users, covering 785,550 daily transactions. We limit our analysis to book return delays, only. In doing so, we restrict the original sample to 310,726 transactions, by 8,045 users. We justify this choice based on the conveniently quantifiable fact that, once a user has a book return delay, he or she starts receiving periodic e-mail reminders through the library's electronic system (Pergamum $)^{1}$.

The data contain information on users' socioeconomic characteristics - such as their gender, date of birth, and address - as well as library's confidential information, with each user's identification number, category (high $\mathrm{school}^{2}$, undergraduate, master, graduate, former student, professor, and employee) and area of study (management, accounting, economics, international relations, advertising, and secretariat). To assess the importance of inattention in this setting, we estimate (1) via Ordinary Least Squares (OLS):

$$
\text { (1) } \mathrm{Y}_{\text {ist }}=\alpha+\beta \text { (Day of the Week) }+\mathrm{X}_{\text {ist }} \gamma+Z_{\mathrm{st}} \lambda+\delta_{\mathrm{t}}+\theta_{\mathrm{st}}+\varepsilon_{\mathrm{ist}}
$$

Here, $Y_{\text {ist }}$ represents the delay for an individual $i$, in library $s$, at instant $t$. The term "Day of the Week" corresponds to an indicator variable, which assumes unity value for each weekday, and 0 , otherwise. We include user and library characteristics as controls in the regressions below (captured by the term $\alpha$ ), as well as time trends $\left(\delta_{t}\right)$. We also consider alternative ways to control for the existence of distinct time trends in different libraries, by including monthly and yearly trends for each library in the sample (captured by the $\lambda$ and $\theta$ terms). In the case of the term $\varepsilon_{\text {ist, }}$ it has a conditional mean of zero $\left(E\left(\varepsilon_{\text {ist }} \mid \mathrm{s}, \mathrm{t}\right)=0\right)$. The parameter of interest in this context is $\beta$, which measures inattention. It is worth noting that the estimates reported herein do not have a causal interpretation.

\section{Results}

Table 1 presents the results of estimations for the 2005-2015 period. The dependent variable corresponds to the number of delays by each library user in the period. In the table's columns, we add covariates to the specifications to control for time-invariant characteristics of users and libraries. Each column reports estimates for a specific day of the week. The last column contains estimates for all days of the week, excluding Sunday. In all cases, we cluster standard errors by the number of courses offered at the institution ${ }^{3}$ :

\section{**INSERT TABLE 1 AROUND HERE**}

The results in the table suggest the occurrence of a "Friday effect", thus favoring the view that the inattention focused upon here is mostly a procrastination phenomenon. In fact, delays are considerably higher on Fridays, either in the case of estimations for individual weekdays

\footnotetext{
${ }^{1}$ This system provides technology services for several libraries in Brazil. Users receive reminders one day before the return of the book is due, and one day after such due date. After that period, they start receiving reminders every three days for each library item they have borrowed and not returned.

2 The private institution under study also offers secondary education equivalent to the high school level in the U.S. High School students comprise 1.37\% of the student body during the 2005-2015 period.

${ }^{3}$ There were 219 such courses offered during the 2005-2015 period. These courses differ with respect to areas of study (management, economics, accounting, international relations, advertising, and secretariat) that a student may choose when he or she enrolls in the institution.
} 
( $26 \%$ higher than other days of the week), or in the case of all weekdays ( $45 \%$ higher than delays on Sundays).

In table 2, we report the results of estimations based on (1), but considering the influence of exam weeks, only. We do this to verify if alternative events that could possibly proxy for inattention also affect return delays, favoring the view that inattention could be strategic in nature. Given that we have access to official institution information, we can build specific dates for exams, as well as close dates (one day, three days, and seven days before and after each event).

\section{**INSERT TABLE 2 AROUND HERE**}

In the case of the results reported above, we could not find a robust empirical pattern consistent with strategic inattention as defined earlier. For most specifications, there is not a robust pattern in delays in returning borrowed library books across these dates. In the case of exam weeks, there is a contemporaneous rise in delays, accompanied by reductions in close dates. These results are hard to reconcile with inattention explanations based on strategic considerations. We conclude that there is a significant effect of Fridays on return delays that seems to be explained by inattentive behavior mostly due to procrastination ${ }^{4}$.

\section{Conclusion}

This paper measures inattention in a novel setting, an information commons. We report the occurrence of a "Friday effect": inattention, as measured by delays in returning books checked out from a library, is consistently higher on Fridays, when compared to any other day of the week. The results reported in this paper favor the view that inattention is mostly a procrastination phenomenon, instead of based on strategic considerations.

\footnotetext{
${ }^{4}$ In the appendix, we present several robustness checks related to the main results reported in this section.
} 


\section{References}

Apesteguia, J., Funk, P., \& Iriberri, N. (2013). Promoting rule compliance in daily-life: evidence from a randomized field experiment in the public libraries of Barcelona. European Economic Review, 64(2), 266-284. http://doi.org/10.1016/j.euroecorev.2013.08.010

Barber, B. M., \& Odean, T. (2008). All that Glitters: the effect of attention and news on the buying behavior of individual and institutional investors. Review of Financial Studies, 21(2), 785-818. http://doi.org/10.1002/9781118467411.ch7

DellaVigna, S., \& Pollet, J. M. (2009). Investor inattention and Friday earnings announcements. Journal of Finance, 44(2), 709-749. http://doi.org/10.2139/ssrn.843786

Ericson, K. M. (2017). On the interaction of memory and procrastination. Journal of the European Economic Association, 15(3), 692-719. http://doi.org/10.3386/w20381

Gabaix, X. (2017). Behavioral inattention (NBER Working Paper Series No. 24096). Cambridge. http://doi.org/10.3386/w24096

Guiso, L., Sapienza, P., \& Zingales, L. (2013). The determinants of attitudes toward strategic default on mortgages. Journal of Finance, 68(4), 1473-1515. http://doi.org/10.1111/jofi.12044

Hirshleifer, D., Lim, S. S., \& Teoh, S. H. (2009). Driven to distraction: extraneous events and underreaction to earnings news. Journal of Finance, 64(5), 2289-2325. http://doi.org/10.1111/j.1540-6261.2009.01501.x

Simon, H. A. (1955). A behavioral model of rational choice. Quarterly Journal of Economics, 49(1), 99-118. http://doi.org/10.2307/1884852 


\section{TABLES}

Table 1

Delays in Weekdays

OLS Estimates, 2005-2015

\begin{tabular}{|c|c|c|c|c|c|c|c|c|}
\hline VARIABLES & $\begin{array}{c}(1) \\
\text { Delays }\end{array}$ & $\begin{array}{c}(2) \\
\text { Delays } \\
\end{array}$ & $\begin{array}{c}(3) \\
\text { Delays }\end{array}$ & $\begin{array}{c}(4) \\
\text { Delays } \\
\end{array}$ & $\begin{array}{c}(5) \\
\text { Delays } \\
\end{array}$ & $\begin{array}{c}(6) \\
\text { Delays } \\
\end{array}$ & $\begin{array}{c}(7) \\
\text { Delays } \\
\end{array}$ & $\begin{array}{c}(8) \\
\text { Delays } \\
\end{array}$ \\
\hline Monday & $\begin{array}{c}-0.16^{* * * *} \\
(0.006)\end{array}$ & & & & & & & $\begin{array}{l}0.10 * * * \\
(0.008)\end{array}$ \\
\hline Tuesday & & $\begin{array}{c}-0.11 * * * \\
(0.007)\end{array}$ & & & & & & $\begin{array}{c}0.14 * * * \\
(0.009)\end{array}$ \\
\hline Wednesday & & & $\begin{array}{c}-0.01 * * * \\
(0.005)\end{array}$ & & & & & $\begin{array}{c}0.21 * * * \\
(0.009)\end{array}$ \\
\hline Thursday & & & & $\begin{array}{c}0.11 * * * \\
(0.010)\end{array}$ & & & & $\begin{array}{l}0.32 * * * * \\
(0.012)\end{array}$ \\
\hline Friday & & & & & $\begin{array}{c}0.26 * * * \\
(0.010)\end{array}$ & & & $\begin{array}{c}0.45 * * * \\
(0.013)\end{array}$ \\
\hline Saturday & & & & & & $\begin{array}{c}0.07 * * * \\
(0.008)\end{array}$ & & $\begin{array}{c}0.29 * * * \\
(0.012)\end{array}$ \\
\hline Sunday & & & & & & & $\begin{array}{c}-0.23 * * * * \\
(0.008)\end{array}$ & \\
\hline User Characteristics & Yes & Yes & Yes & Yes & Yes & Yes & Yes & Yes \\
\hline Library Characteristics & Yes & Yes & Yes & Yes & Yes & Yes & Yes & Yes \\
\hline Libraries x Months & Yes & Yes & Yes & Yes & Yes & Yes & Yes & Yes \\
\hline Libraries x Years & Yes & Yes & Yes & Yes & Yes & Yes & Yes & Yes \\
\hline Observations & 310,726 & 310,726 & 310,726 & 310,726 & 310,726 & 310,726 & 310,726 & 310,726 \\
\hline Adj. R-squared & 0.0764 & 0.0708 & 0.0660 & 0.0704 & 0.0868 & 0.0670 & 0.0705 & 0.106 \\
\hline
\end{tabular}

Notes: (a) The dependent variable in the specifications corresponds to the average delays (in days) per user in each library studied in this paper. (b) Standard errors clustered by course (reported in parentheses). (c) "User Characteristics" correspond to a set of dummies for users' gender (female $=1$ ), academic financial support (scholarship $=1$ ), group ages (18-23, 24-30, 31-40, 41-50, 51-60, 60+), category (undergraduate, master, graduate, and former student, employee, and professor), area of study (management, accounting, economics, advertising, international relations, and secretariat), and time at college ( 0 to 4 years). (d) "Library Characteristics" correspond to a set of dummies for each library in the sample, including their location, and staff size, as well as their composition of books (management, accounting, economics, and law). (e) The terms "Libraries x Months" and "Libraries x Years" correspond to interactions between libraries and months and libraries and years, respectively. (f) Statistical significance: $* \mathrm{p}<0.10, * * \mathrm{p}<0.05, * * * \mathrm{p}<0.01$. 
Table 2

Delays during Exam Weeks

OLS Estimates, 2005-2015

\begin{tabular}{|c|c|c|c|c|c|c|c|}
\hline VARIABLES & $\begin{array}{c}(1) \\
\text { Delays } \\
\end{array}$ & $\begin{array}{c}(2) \\
\text { Delays } \\
\end{array}$ & $\begin{array}{c}(3) \\
\text { Delays } \\
\end{array}$ & $\begin{array}{c}(4) \\
\text { Delays }\end{array}$ & $\begin{array}{c}(5) \\
\text { Delays } \\
\end{array}$ & $\begin{array}{c}(6) \\
\text { Delays } \\
\end{array}$ & $\begin{array}{c}(7) \\
\text { Delays } \\
\end{array}$ \\
\hline Exams & $\begin{array}{c}0.06 * * * \\
(0.011)\end{array}$ & & & & & & \\
\hline Exams $(\mathrm{t}-1)$ & & $\begin{array}{c}-0.02 * * * \\
(0.009)\end{array}$ & & & & & \\
\hline Exams $(\mathrm{t}-3)$ & & & $\begin{array}{c}-0.03 * * * \\
(0.007)\end{array}$ & & & & \\
\hline Exams $(\mathrm{t}-7)$ & & & & $\begin{array}{c}-0.02 * * * \\
(0.008)\end{array}$ & & & \\
\hline Exams $(t+1)$ & & & & & $\begin{array}{c}-0.02 * * * \\
(0.006)\end{array}$ & & \\
\hline Exams $(t+3)$ & & & & & & $\begin{array}{l}-0.02 * * \\
(0.008)\end{array}$ & \\
\hline Exams $(t+7)$ & & & & & & & $\begin{array}{c}-0.02 * * * \\
(0.007)\end{array}$ \\
\hline User Characteristics & Yes & Yes & Yes & Yes & Yes & Yes & Yes \\
\hline Library Characteristics & Yes & Yes & Yes & Yes & Yes & Yes & Yes \\
\hline Libraries x Months & Yes & Yes & Yes & Yes & Yes & Yes & Yes \\
\hline Libraries x Years & Yes & Yes & Yes & Yes & Yes & Yes & Yes \\
\hline Observations & 310,726 & 310,725 & 310,724 & 310,722 & 310,725 & 310,724 & 310,721 \\
\hline Adj. R-squared & 0.0665 & 0.0661 & 0.0661 & 0.0661 & 0.0661 & 0.0661 & 0.0661 \\
\hline
\end{tabular}




\title{
Paying attention to inattention Evidence from Libraries
}

\begin{abstract}
Appendix
This Appendix contains the results of several tests aimed at checking the robustness of the main results reported in the paper. In Tables A1 to A4, we present estimates of inattention based on distinct samples. Table A1 reports results for distinct library units (Liberdade, Largo do São Francisco (San Fran), and Pinheiros). Table A2 contains results by user category (high school, undergraduate, master, graduate students, former students, employees, and professors), while table A3 contains results for distinct courses (management, accounting, economics, international relations, advertising, secretariat, and other courses). Finally, Table A4 reports the results of estimations for samples based on the time that users have been in the institution (0 year, 1 year, 2 years, etc.). In all cases, we want to check whether the main results are robust to minor changes in the original sample.
\end{abstract}

Table A1

Robustness: Delays by Library Unit OLS Estimates, 2005-2015

\begin{tabular}{lccc}
\hline & $(1)$ & $(2)$ & $(3)$ \\
VARIABLES & Liberdade & San Fran & Pinheiros \\
\hline Friday & $0.26^{* * *}$ & $0.23^{* * *}$ & $0.26^{* * *}$ \\
& $(0.010)$ & $(0.025)$ & $(0.035)$ \\
User Characteristics & Yes & Yes & Yes \\
Library Characteristics & Yes & Yes & Yes \\
Libraries x Months & Yes & Yes & Yes \\
Libraries x Years & Yes & Yes & Yes \\
Observations & 279,043 & 28,278 & 3,405 \\
Adj. R-squared & 0.0883 & 0.0748 & 0.0865 \\
\hline
\end{tabular}

Notes: (a) The dependent variable in the specifications corresponds to the average delays (in days) per user in each library studied in this paper. (b) Standard errors clustered by course (reported in parentheses). (c) "User Characteristics" correspond to a set of dummies for users' gender (female $=1$ ), academic financial support (scholarship = 1), group ages $(18-23,24-30,31-40,41-50,51-60$, $60+$ ), category (undergraduate, master, graduate, and former student, employee, and professor), area of study (management, accounting, economics, advertising, international relations, and secretariat), and time at college ( 0 to 4 years). (d) "Library Characteristics" correspond to a set of dummies for each library in the sample, including their location, and staff size, as well as their collection of books (management, accounting, economics, and law). (e) The terms "Libraries X Months" and "Libraries X Years" correspond to interactions between libraries and months and libraries and years, respectively. (f) Statistical significance: $* \mathrm{p}<0.10, * * \mathrm{p}<0.05$, $* * *$ $\mathrm{p}<0.01$. 
Table A2

Robustness: Delays by User Category

OLS Estimates, 2005-2015

\begin{tabular}{|c|c|c|c|c|c|c|c|}
\hline VARIABLES & $\begin{array}{c}\text { (1) } \\
\text { High School }\end{array}$ & $\begin{array}{c}(2) \\
\text { Undergraduate }\end{array}$ & $\begin{array}{c}\text { (3) } \\
\text { Master }\end{array}$ & $\begin{array}{c}\text { (4) } \\
\text { Graduate }\end{array}$ & $\begin{array}{c}\text { (5) } \\
\text { Former Stdt. }\end{array}$ & $\begin{array}{c}(6) \\
\text { Employee }\end{array}$ & $\begin{array}{c}(7) \\
\text { Professor }\end{array}$ \\
\hline Friday & $\begin{array}{c}0.33 * * * \\
(0.030)\end{array}$ & $\begin{array}{c}0.28 * * * \\
(0.006)\end{array}$ & $\begin{array}{c}0.03 \\
(0.072)\end{array}$ & $\begin{array}{c}0.25 * * * \\
(0.013)\end{array}$ & $\begin{array}{c}0.27 * * * \\
(0.021)\end{array}$ & $\begin{array}{c}0.19 * \\
(0.106)\end{array}$ & $\begin{array}{c}0.03 * \\
(0.017)\end{array}$ \\
\hline User Characteristics & Yes & Yes & Yes & Yes & Yes & Yes & Yes \\
\hline Library Characteristics & Yes & Yes & Yes & Yes & Yes & Yes & Yes \\
\hline Libraries x Months & Yes & Yes & Yes & Yes & Yes & Yes & Yes \\
\hline Libraries x Years & Yes & Yes & Yes & Yes & Yes & Yes & Yes \\
\hline Observations & 4,253 & 207,134 & 9,995 & 69,716 & 12,296 & 1,109 & 6,223 \\
\hline Adj. R-squared & 0.0891 & 0.0697 & 0.113 & 0.0704 & 0.0878 & 0.152 & 0.111 \\
\hline
\end{tabular}

Notes: see Table A1 above.

Table A3

Robustness: Delays by Course OLS Estimates, 2005-2015

\begin{tabular}{|c|c|c|c|c|c|c|c|}
\hline VARIABLES & $\begin{array}{c}(1) \\
\text { Management }\end{array}$ & $\begin{array}{c}(2) \\
\text { Accounting }\end{array}$ & $\begin{array}{c}(3) \\
\text { Economics }\end{array}$ & $\begin{array}{c}(4) \\
\text { Int.Relations }\end{array}$ & $\begin{array}{c}(5) \\
\text { Advertising }\end{array}$ & $\begin{array}{c}(6) \\
\text { Secretariat }\end{array}$ & $\begin{array}{l}(7) \\
\text { Other }\end{array}$ \\
\hline Friday & $\begin{array}{c}0.26 * * * \\
(0.015)\end{array}$ & $\begin{array}{c}0.25 * * * \\
(0.021)\end{array}$ & $\begin{array}{l}0.28 * * \\
(0.010)\end{array}$ & $\begin{array}{c}0.29 * \\
(0.039)\end{array}$ & $\begin{array}{c}0.32 * * * \\
(0.004)\end{array}$ & $\begin{array}{c}0.32 * \\
(0.033)\end{array}$ & $\begin{array}{l}0.18 * * * \\
(0.057)\end{array}$ \\
\hline User Characteristics & Yes & Yes & Yes & Yes & Yes & Yes & Yes \\
\hline Library Characteristics & Yes & Yes & Yes & Yes & Yes & Yes & Yes \\
\hline Libraries x Months & Yes & Yes & Yes & Yes & Yes & Yes & Yes \\
\hline Libraries x Years & Yes & Yes & Yes & Yes & Yes & Yes & Yes \\
\hline Observations & 101,547 & 117,718 & 42,696 & 11,722 & 14,520 & 6,832 & 15,691 \\
\hline Adj. R-squared & 0.0694 & 0.0926 & 0.0706 & 0.0858 & 0.0880 & 0.0767 & 0.141 \\
\hline
\end{tabular}

Notes: see Table A1 above.

Table A4

Robustness: Delays by Time at the Institution OLS Estimates, 2005-2015

\begin{tabular}{lcccccc}
\hline & $(1)$ & $(2)$ & $(3)$ & $(4)$ & $(5)$ & $(6)$ \\
VARIABLES & 0 year & 1 year & 2 years & 3 years & 4 years & 5+ years \\
\hline Friday & $0.29^{* * *}$ & $0.28^{* * *}$ & $0.26^{* * *}$ & $0.24 * * *$ & $0.21 * * *$ & $0.21^{* * *}$ \\
& $(0.015)$ & $(0.011)$ & $(0.013)$ & $(0.007)$ & $(0.029)$ & $(0.034)$ \\
User Characteristics & Yes & Yes & Yes & Yes & Yes & Yes \\
Library Characteristics & Yes & Yes & Yes & Yes & Yes & Yes \\
Libraries x Months & Yes & Yes & Yes & Yes & Yes & Yes \\
Libraries x Years & Yes & Yes & Yes & Yes & Yes & Yes \\
Observations & 69,779 & 82,025 & 59,960 & 46,110 & 15,599 & 37,253 \\
Adj. R-squared & 0.0925 & 0.0875 & 0.0837 & 0.0733 & 0.0638 & 0.103 \\
\hline
\end{tabular}

Notes: see Table A1 above.

According to the results reported in this section, we conclude that the previous results remain qualitatively the same. This lends a great deal of confidence to our inference related to the occurrence of a robust "Friday effect" in this context. 